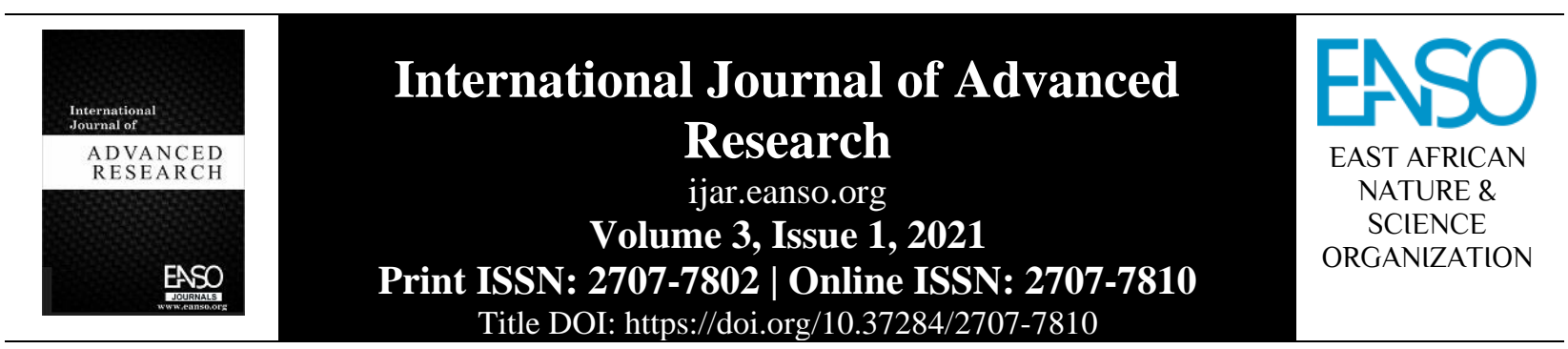

Original Article

\title{
Factors and Constraints Hindering Effective Municipal Solid Waste Management Systems in Sub-Saharan Africa: Case Study of Northern Uganda.
}

\author{
Joel-Owiny Ongia ${ }^{1}$, Loy Turyabanawe ${ }^{1}$, Bernard Barasa $^{l}$, Andrew Mulabbi ${ }^{2} * \&$ Gertrude Akello $^{l}$ \\ ${ }^{1}$ Department of Geography and Social Studies, Kyambogo University, P. O. Box 1, Kyambogo, Kampala, Uganda. \\ ${ }^{2}$ Department of Humanities, Muni University, P. O. Box 72, Arua. \\ * Author for Correspondence email: mulabbiandrew@yahoo.com.
}

Article DOI: https://doi.org/10.37284/ijar.3.1.431

\section{Publication Date: ABSTRACT}

06 October 2021 In developing countries, little information is available about solid-waste Keywords: characteristics, determinants for adoption and performance-evaluation of municipal-waste management systems in Municipals. This study aimed: to characterize the municipal solid-wastes, collection, dumping and evaluate the efficiency and reliability of Municipal solid-waste management system. A total of 200 households were randomly sampled and interviewed. Data was analysed using Binary-Logistic Regression model to determine factors influencing collection and dumping of solid wastes. Results showed that biodegradable/organic wastes comprise a major fraction of solid-wastes produced. Factors that influenced solid-waste collection and dumping included: household-age, unavailability of solid-waste containers, inadequate collection/dumping space and weak legal-enforcement against poordumping. The waste system is constrained by inadequate transport facilities, inadequate space for temporal dumping; and lack of legal enforcement in matters of solid-waste poor handling. These have made the systems ineffective and unreliable. This study recommends involvement of all stakeholders in innovative approaches to uphold sustainable municipal sanity.

\section{APA CITATION}

Ongia, J. O., Turyabanawe, L., Barasa, B., Mulabbi, A., \& Akello, G. (2021). Factors and Constraints Hindering Effective Municipal Solid Waste Management Systems in Sub-Saharan Africa: Case Study of Northern Uganda. International Journal of Advanced Research, 3(1), 130-149. https://doi.org/10.37284/ijar.3.1.431

\section{CHICAGO CITATION}

Ongia, Joel-Owiny, Loy Turyabanawe, Bernard Barasa, Andrew Mulabbi, \& Gertrude Akello. 2021. "Factors and Constraints Hindering Effective Municipal Solid Waste Management Systems in Sub-Saharan Africa: Case Study of Northern Uganda." International Journal of Advanced Research 3 (1), 130-149. https://doi.org/10.37284/ijar.3.1. 431. 


\section{HARVARD CITATION}

Ongia, J. O., Turyabanawe, L., Barasa, B., Mulabbi, A., \& Akello, G. (2021) "Factors and Constraints Hindering Effective Municipal Solid Waste Management Systems in Sub-Saharan Africa: Case Study of Northern Uganda.", International Journal of Advanced Research, 3(1), pp. 130-149. doi: 10.37284/ijar.3.1. 431.

\section{IEEE CITATION}

J. O. Ongia, L. Turyabanawe, B. Barasa, A. Mulabbi, \& G. Akello, "Factors and Constraints Hindering Effective Municipal Solid Waste Management Systems in Sub-Saharan Africa: Case Study of Northern Uganda.", IJAR, vol. 3, no. 1, pp. 130-149, Oct. 2021.

\section{MLA CITATION}

Ongia, Joel-Owiny, Loy Turyabanawe, Bernard Barasa, Andrew Mulabbi, \& Gertrude Akello. "Factors and Constraints Hindering Effective Municipal Solid Waste Management Systems in Sub-Saharan Africa: Case Study of Northern Uganda.". International Journal of Advanced Research, Vol. 3, no. 1, Oct. 2021, pp. 130-149, doi:10.37284/ijar.3.1. 431.

\section{INTRODUCTION}

In Uganda, most waste generated in the municipalities is not adequately collected. Municipal solid wastes include wastes generated from offices, hotels, shopping complexes/shops, schools, institutions, and from municipal services such as street cleaning and maintenance of recreational areas as put forward by [1]. Wastes from municipalities is usually heterogeneous and has variable physical characteristics depending on their sources [2]. He explained that the main component of municipal solid waste (MSW) comprises the biomass material such as food, paper, wood waste, clothes rage, rubber, plastics and other daily used discarded materials. These define the socio-economic structure and in particular the income levels of the people and its component portrays their consumption patterns, as observed by [3]. In this study, therefore, municipal solid waste is any used product discarded as useless after it has lost value in the face of its first user.

Globally, the composition of municipal solid waste (MSW) can be classified according to each country's income level. A review of the global MSW situation reported that the annual global MSW generation amount was at 1.3 billion tonnes and the global MSW generation rate at 1.2 $\mathrm{kg} / \mathrm{capita} /$ day [4]. They speculated that by 2025 , this will likely increase to about $1.42 \mathrm{~kg} / \mathrm{capita} /$ day $(2.2$ billion tonnes of MSW per year). Data from Asia confirms that the more developed countries like Japan, Laos and Thailand, have more municipal waste generated per capita as presented by [5]. In Africa, the rate of urbanization (estimated at 3.5\% annually) has increased Municipal waste generation tremendously due to increased industrialization and modernization of agriculture as forwarded by [6]
However, according to [7], indiscriminate disposal of MSW is a major nuisance in urban areas that have contaminated groundwater and degraded the soil quality in sub-Saharan Africa. Omekwe [8] contends that socio-economic factors such as income status, educational status and employment status positively relate with solid waste collection and disposal by the residents. The concern of this study was to find out how best municipal solid waste should be collected and disposed of in urban towns including Lira municipality and also identify the factors that relate to its collection and disposal modalities and how or why?

Even though the overall goal of urban solid waste management is to collect, treat and dispose of solid waste generated by all urban dwellers, $30 \%-60 \%$ of all the urban solid wastes is uncollected, and less than $50 \%$ of the population is served as noted by Kinobe et al. [9]. It is also noted that most municipal authorities tend to allocate their financial resources to wealthier areas where residents are always politically influential, and pay high taxes [10]. As a result, inefficient municipal solid waste management system increases disease transmission, contaminate ground and surface water, create greenhouse gas emissions, damage ecosystem services, discourages tourism and other business activities as was observed by Chinasho [11] and Fenta [12]. This study, therefore, sought to find out the different collection and disposal modalities and how it affects people's life and the environment as well.

Municipal solid waste generation rate increases with an increase in economic development, degree of industrialization, and rate of urbanization as noted by Kaza et al [13]. Accordingly, Lira Municipality is one of the highly expanding and rapidly growing 
towns in Uganda [14]. If the current annual population growth rate of $3.6 \%$ continues, the municipal population would double within 5 years and increase pressure on municipal solid waste management and lead to an outbreak of diseases [14]; thus, the need for adequate solid waste management is unquestionable [5;15]. It is against this background that the study chose to characterize the solid waste, assess the collection and dumping operations, its efficiency and reliability, and gauge the constraints and opportunities. This is based on the fact that Lira is one of the first growing urban towns facing the same problems as other urban towns and cities in Uganda with a likelihood of even worsening if the problem is not addressed.

\section{MATERIALS AND METHODS}

\section{Description of the Study Area}

Lira Municipality in Northern Uganda is geographically located at latitude $20^{\circ} 17^{\prime}$ north of the equator and longitude $32^{\circ} 56^{\prime}$ east of the principal meridian [14]. The Municipality covers a land area of 7,745 hectares. It lies along the highway between Gulu and Soroti and is the main municipal, administrative, and commercial Centre of Lira district and the whole of the Lango region (Figure 1).

Figure 1: Map of Lira Municipality

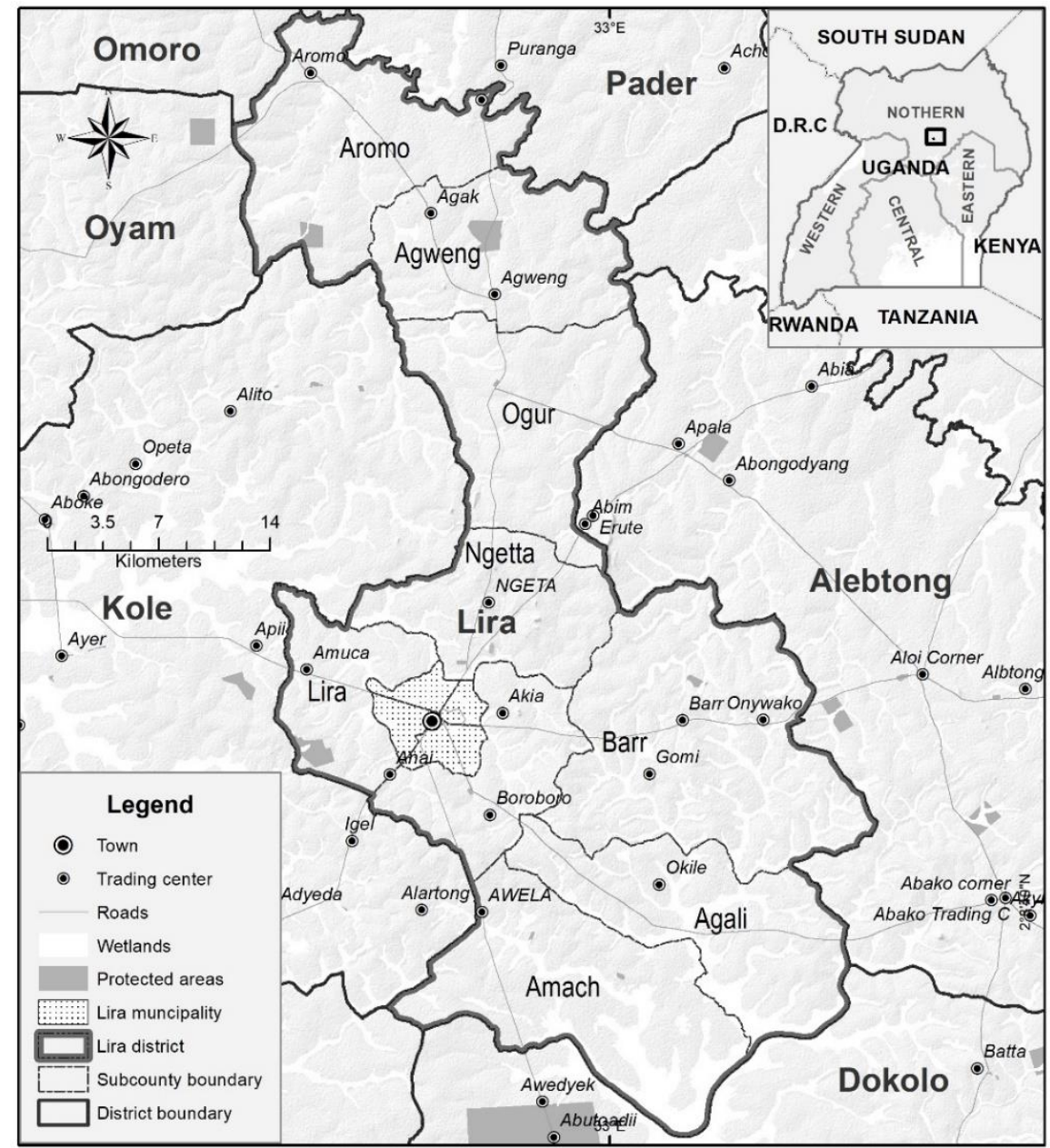

Lira Municipality exhibits a uni-modal rainfall pattern with a single rainfall maximum. The rainy season stretches from March to November with a short dry spell in June and July. The dry season stretches from December to March. Ngetta Meteorological Station figures indicate that the 
amount of rainfall ranges from $1000 \mathrm{~mm}$ to 1600 $\mathrm{mm}$ per annum [16]. The average temperature of Lira Municipality ranges from $22{ }^{\circ} \mathrm{C}$ and $26^{\circ} \mathrm{C}$ but the diurnal temperature range is high in the dry season and may reach $40{ }^{\circ} \mathrm{C}$. This climatic type encourages quick decay of solid waste organic matter which dissolves to form garbage soup which contaminates drinking water in the springs through seepage and provides a conducive atmosphere to vices of health hazards multiplication.

The relief of Lira Municipality is generally flat and gently undulating. The altitude is between 1075 and 1100 meters above sea level [17]. This kind of terrain promotes the carriage of solid waste by running water to low land areas usually pronounced causing a health problem. The soils of Lira Central Division are categorized as ferruginous sandy loam. The soil has a high percentage of sandy soil and therefore it is vulnerable to erosion. Since the soil is sandy, it has a low water retention capacity and a high rate of water infiltration and this implies that the infiltration of decayed indiscriminately discarded wastes soup into the underground spring flow lines is very high making the study eminent.

The Municipal council is a Centre for economic and industrial activities, with better social services and this has attracted a large population. The dwellers carry out trade, industrial manufacturing mainly medium size dealing in small-scale agro-processing, informal small sector ranging from metal fabrication, timber works to commercial shops [14]. These activities produce a bigger amount of solid waste into the waste streams that attract attention for effective management. According to UBOS [14] National population and housing census, Lira municipality had a population of 99,511 and household population of 25,396. The Municipality comprises four Division Councils namely: - Adyel Division, Lira Central, Ojwina Division and Railways Division as lower local governments under the Municipal Council. Under these Divisions are lower Councils numbering twenty-five parishes or wards (LC II) and sixty-six villages.

\section{Study Approach}

The study employed a municipal investigative approach within the municipality. All the four divisions were selected for detailed analysis. The study was based on two assumptions. The first was that solid waste management system in Lira municipality has never been effective. This idea was rooted on the paradigm of Urban sustainability theory and practice [18] that; 'Cities are at the heart of the problems facing this planet, but developing a positive and sustainable mode of urban living is the only way that we will be able to sustain social life as we know'. It was also based on the directly observed situation on the ground in Lira municipality.

\section{Sample Design}

The cross-sectional research design was used in the study. Households were randomly sampled to avoid biases and the sampled ones provide the information that would be representative of what the other nonselected ones would provide since they are on the same locality and getting the same management services. The household target was on household heads irrespective of whether male or female. This made the total population of 200 households as proposed by the study. Basing on UBOS [14] household population of 25,396 in all the four divisions the study employed multi-stage household sampling formula [19]. To ensure adequate sample an addition of 77 households was made to realize 200 households in expectation for more radiates of households. Multi-stage sampling was used because it divides the population into distinct groups in a way that allows the study to act within his means on the desired information as programmed in both time and financial issues. It also allows for flexibility by the study to employ random sampling after determination of the groups.

Household heads, heads of business units who were purposely selected whether Male or Female because they are in charge of waste collection and disposal in their household/ business units since they provided informed consent to their members to participate in waste management practices given their knowledge in waste hazards. Waste collection crew were included in the study as they provided valid and dependable information on waste constraints, managerial constraints and any other knowledge on collection and disposal effectiveness. Lastly, the municipal and division officials; especially the chief administrative officer of the municipality, assistant town clerks in the divisions 
were included. This is because they are the spearheads of municipal planning, and are technical supervisors and advisors in case of any technical fault in the municipality. The study used structured questionnaire sheets, direct interview guides, direct observation checklists, camera, focus group discussion guides, weighing scale and Key informants.

\section{Data Analysis}

The collected data was analysed using two different strategies. This was the descriptive strategy and inferential mode. By descriptive strategy, information on socio-demographic characteristics of the respondents, solid waste categories, collection and dumping operations from interview guides and questionnaires, focus group discussions, and key informants was coded using numerical values $(1,2,3 \ldots)$ and their computed response sums analysed using SPSS statistical tool package. The data was grouped into descriptive percentages, frequency tables and pie charts. Direct visualization from observation checklists and photography information were collected and analysed using personal judgment by the study. Descriptive narratives and quotes supported by illustrations were also used to present some results.

With the inferential mode, the study used this strategy to establish the cardinal factors that influence the ways the wastes were being collected and dumped in the various divisions of the municipality. In this case, the study employed a Binary Logistic Regression model which was appropriate, as it took only one of two possible values. The study chose to use the model from his experience that most scholars have ever applied it in determining such phenomena and ever yielded best and the expected outcomes. The formula for the analysis is $\mathrm{Y}=\mathrm{B}_{0}+\mathrm{Bx}_{1}+\mathrm{Bx}_{2}+\mathrm{Bx}_{3} \ldots \ldots$; where $\mathrm{X}$ independent variables influencing the collection and dumping of municipal solid waste and $\mathrm{Y}$ dependent variables is the result to be measured.
The independent variables measured in the study were age, duration lived in the place (years), presence of waste collection services, who is in charge of the provision, types and states of waste packaging containers, adequacy of dumping space, presence of waste by-laws and its enforcement etc. The independent variables named were coded and assigned numerical values ( 1 or 2 ) to stand for either 'Yes' or 'No' for the hypotheses $\left(\mathrm{H}_{0}\right)$ being tested as shown in the table 1 below;

However, before using the Logistic Regression Model to analyse the collected binary data, suitability tests to the Model was carried to ascertain the following:

- Multi-collinearity: Multivariate correlation analysis was used to determine the correlation among independent variables, so that if the Pearson correlation was more than 0.5 , then there would be multi-collinearity and when the correlation coefficients are less than 0.5 , then the model would not be affected by the multicollinearity among the predictors. The variance inflation factor was also used in this study and it was less than two in all predictor variables, confirming that there was no multi-collinearity problem.

- Chi-square and R-square values: Chi-square was used to test the null hypothesis $\left(\mathrm{H}_{\mathrm{o}}\right)$. The logistic regression model achieves goodness of fit when the Chi-square test statistics are highly significant at $1.0 \%(\mathrm{p}<0.00001)$. In this study, the R-square value of the Cox and Snell test, and the Nagelkerke test would be between 0 and 1 which supports the goodness of fit of the model.

- Percentage: When the value of the Percent Correction Prediction is high, this means that the ability or the accuracy of the prediction is high. 
International Journal of Advanced Research, Volume 3, Issue 1, 2021

Article DOI: https://doi.org/10.37284/ijar.3.1.431

Table 1: Showing independent variables used in testing the hypothesis

\begin{tabular}{|c|c|c|}
\hline Variable & Code & Data Entry \\
\hline \multicolumn{3}{|l|}{ Personal factors } \\
\hline Age bracket & Age & $(18-25)=1,(26$-above $)=2$ \\
\hline Year lived in community & Duration & $(1-5$ yrs $)=1,(6$-above $)=2$ \\
\hline Education level & Education & $\begin{array}{l}\text { Primary }=I, \text { secondary- } \\
\text { above }=2\end{array}$ \\
\hline What is used for carrying waste? & Container & $\begin{array}{l}\text { Old bucket/sacks }=1, \\
\text { waste bins }=2\end{array}$ \\
\hline \multicolumn{3}{|l|}{ Waste Management Factors } \\
\hline Availability of waste collection services & Waste services & Yes $=1$, No $=2$ \\
\hline Who is in charge of the collection? & In charge & $\begin{array}{l}\text { Municipal government }=1 \text {, } \\
\text { private collectors }=2\end{array}$ \\
\hline Presence of adequate collection space & Space & Yes $=1$, No $=2$ \\
\hline Sensitization on waste problems & Sensitization & Yes $=1, \mathrm{No}=2$ \\
\hline Availability of waste dumping by-laws & By-laws & Yes $=1$, No $=2$ \\
\hline Who enforces the waste By-laws? & Enforcement & $\begin{array}{l}\text { Local councillors }=1 \text {, health } \\
\text { workers }=2\end{array}$ \\
\hline $\begin{array}{l}\text { Have legal steps been taken against illegal } \\
\text { disposal? }\end{array}$ & Legal steps & Yes $=1$, No $=2$ \\
\hline \multicolumn{3}{|l|}{ Attitudinal factors } \\
\hline Are you willing to pay for collection? & WTP & Yes $=1$, No $=2$ \\
\hline Are there any gains in solid waste? & Gains & $\mathrm{Yes}=1, \mathrm{No}=2$ \\
\hline
\end{tabular}

\section{Evaluation of Municipal Solid Waste Management}

The performance indicators adopted by this study to evaluate the performance of municipal solid waste management were efficiency and reliability. According to the key informants interviewed these were the main measures they used to assess the municipal soil waste management system they had implemented in the Municipality. On the reliability of waste management operations, the study focused on the mechanical condition of garbage trucks, solid waste collection coverage, waste by-laws existence, and By-laws enforcing entity. While, the studied indicators of efficiency were: collection frequency, collection entity, time at which collection the operation took place, and transport mechanism adequacy used.

\section{Household Solid Waste Weighing}

The study used 2 pieces of medium single sided glass face reading weighing scale of 100-kilogram net weight. This study provided empty sacks of 50 $\mathrm{kg}$ weight to the sampled homes. Each sack was labelled using marker pens with writing such as vegetable matter, food waste, plastic, glass etc. Depending on what they wanted the home dwellers to put the particular type of waste and this would be checked and measured by research assistants after every two days for at least three times in a particular household and results recorded for computation. All the selected households in the study (200) were selected to establish the type of waste usually generated in the municipality with weighted amounts to avoid assumptions. The weighing scale was first checked, tested and stamped by the Uganda Bureau of Statistics for its efficiency and reliability.

\section{RESULTS}

\section{Socio-Economic Characteristics of Respondents}

The descriptive statistics of the respondents are presented in Table 2. The population of female household heads was greater than male in all areas of the municipality. It showed that women are the most available caregivers in homes and business units followed by men. Household hygiene, in this 
case, was a concern of women in most cases in households in Lira municipality. The finding shows that Lira municipality comprises highly of young people aged 26-35, followed by middle-aged between 36-60, and few people at late ages of 60 years and above. It further tells that strong and ablebodied active people form the greater populace group than elderly dependent age group. It is thus a municipality of active and productive dwellers expected to uphold a high level of sanity. The study also shows that Lira municipality population is dominated by mostly literate people who received secular education followed by a few falling in the non-formal category. Also, a greater number of municipal occupants received secondary education level followed by primary level, tertiary level with very few that never went to school (Table 2).
However, key informants and focus group reports showed that efforts were made through NGOs and church groups to provide adult literacy learning to most un-schooled peoples in the municipality to make them at least literate. This reveals that Lira municipality has mostly literate occupants. The study reveals that Lira municipality is inhabited by informed people who have good knowledge scope to uphold sanity in their environment but could be handicapped by some missing links. Most household are involved in business, farming, and public service. People in high-profit maximization sectors; especially business/trade and progressive agricultural ventures were able to acquire many homes in the municipality than people employed in non-profit maximization and service delivery; public servants.

Table 2: Demographic characteristics of respondents $(\mathrm{N}=\mathbf{2 0 0})$

\begin{tabular}{lll}
\hline Variable & Description & F/Percentage \\
\hline Age bracket & $(26-35)$ & $102(51)$ \\
& $(36-60)$ & $42(21)$ \\
& $(60$-above) & $36(18)$ \\
\hline Education & None & $21(11)$ \\
& Primary & $49(25)$ \\
& Secondary & $96(48)$ \\
& Tertiary & $34(17)$ \\
\hline Occupation & Farmers & $53(27)$ \\
& Public servant & $33(17)$ \\
& Drivers & $10(5)$ \\
& Teachers & $28(14)$ \\
& Business & $76(38)$ \\
\hline Duration of stay. & Less than 1 year & $9(5)$ \\
& $1-5$ years & $21(11)$ \\
& $5-10$ years & $45(23)$ \\
& 10 years-above & $125(63)$ \\
\hline
\end{tabular}

Characteristics of Solid Waste, Collection Operations and Dumping Systems

The study categorized the wastes under vegetation matter, plastic, polythene, food waste, paper, glass, sawdust, and street debris. The results are presented in form of tables and graphs as shown in Figure 2. The result indicates that organic biodegradable solid wastes are the commonest in the waste stream; especially vegetation matter, food waste, sawdust and paper, followed by in-organic non-bio degradable comprising of plastic, polythene and glass. Organic biodegradable matter is thus in greater use in the municipality than in-organic nonbiodegradable matter. The study shows a unique pattern in that on any type of waste generated vegetation matter and plastic would be most generated with street debris always inclusive. But the greatest pattern of usage is biodegradable matter. Another unique finding from the study shows that street debris which would be neglected from the waste classification is gaining prominence in the waste streams as opposed to glass in all the four divisions of the municipality. 
Figure 2: Solid waste characteristics identified per division in the municipality

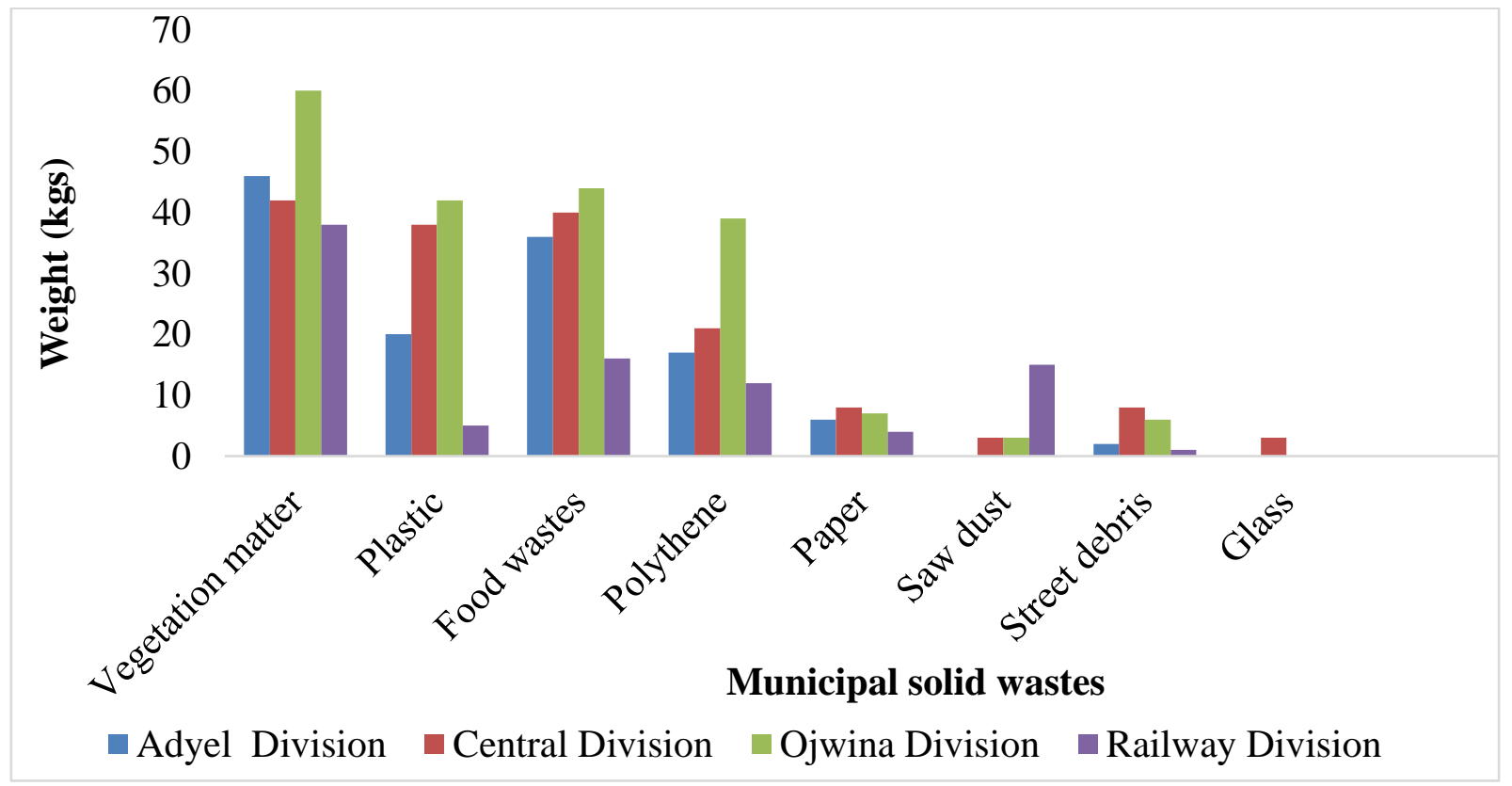

Table 3 shows that traditional back yard storage mode is still slightly high compared with a polythene bag and community collection bin. Lira municipal council takes sole responsibility in solid waste collection in the whole municipality than private waste collectors. Open dumping is the commonest method followed by landfill in Lira municipality. Most households use hired labour to take their household wastes to temporal collection points.

Table 3: Solid waste storage, collection and dumping operations $(\mathrm{N}=200)$

\begin{tabular}{lll}
\hline Variable & Description & $\mathbf{f ( \% )}$ \\
\hline Storage & Back yard/throw anywhere & $58(29)$ \\
& Polythene bags & $57(29)$ \\
& Refuge sacks/old cans & $35(18)$ \\
& Waste bin & $50(25)$ \\
\hline Collection & Lira municipal council & $159(80)$ \\
& Private waste collectors & $41(21)$ \\
\hline Dumping & Open dumping & $77(39)$ \\
& Landfill & $57(29)$ \\
& Incinerator/open burning & $32(16)$ \\
& Compost yard & $22(11)$ \\
& Sell to users & $12(6)$ \\
\hline Who takes the waste to temporal collection points & Children & $9(5)$ \\
& Wife & $16(8)$ \\
& Housekeeper & $23(12)$ \\
& Hired labour & $152(76)$ \\
\hline
\end{tabular}

137 | This work is licensed under a Creative Commons Attribution 4.0 International License 


\section{Factors Influencing Solid Waste Collection and} Dumping in Lira Municipality

The study employed a statistical model (Binary Logistic Regression). After considering the coefficient of the independent variables and the level of significance of such coefficients, the factors influencing collection and dumping of solid waste in Lira municipality was established as shown (Table 4). Age was realized as very cardinal meaning that with increase in age people become more aware of their surrounding hygiene and solid waste packaging in their area. With the marginal effect of 3.838, the increase in age of dwellers in settlement or work area increases effective waste collection and dumping compared to settlements and workplaces comprising of people of young age bracket who minds less about their surrounding hygiene. A container used for carrying waste to a central collection point (waste container) mattered: This variable had a coefficient of 2.184 and significance level of 0.000 which is below 0.001 . This implies that any improvement in solid waste packaging and carrying items would give conducive condition while taking waste to a central dump. Issues of spillage or soup dirtying the taker will not arise. With the effect of 8.883 , any improvement by providing the best waste carrying containers to the central dumping ground would give $88.83 \%$ improvement in efficient and effective collection and proper dumping.

Presence of adequate collection/dumping space had a coefficient value of -4.403 and significance level of 0.000 which is below 0.001 . With the marginal effect of 0.012 implies that failure to secure some more central dump site will always increase indiscriminate dumping by $1.2 \%$ as opposed to effective collection and dumping practices. Legal enforcement/ step against illegal disposal had a coefficient of 0.008 which is quite below 0.001 . This means that those dwellers who have personal conviction to maintain good surrounding hygiene will package and dump their solid waste in designated central collection point without any forceful reminders and any fears. With the marginal effect of 0.006 means that failure to prosecute any caught practitioners of indiscriminate disposal will lead to degeneration ineffective waste collection and proper dumping by $6 \%$. The Chi-square significance value at 0.001 technically means that at least one of the coefficients of the independent variables is not zero, and demonstrates that the model is suitable for the analysis (Table 5). Also, the model has good predictive ability based on the measure using Pseudo- $\mathrm{R}^{2}$ (Cox and Snell $=0.388$ and Nagelkerke $=0.554$ ). The percentage of Correct Predictions shows that the model can predict correctly at $88.0 \%$.

Table 4: Results of analysis of factors influencing collection and dumping solid waste

\begin{tabular}{|c|c|c|c|c|c|c|}
\hline Variables & B & S.E. & Wald & Df & Sig. & $\operatorname{Exp}(\mathbf{B})$ \\
\hline Household age & 1.564 & .393 & 15.861 & 1 & .000 & 3.838 \\
\hline Duration in the community & 1.151 & .600 & 3.680 & 1 & .055 & 3.162 \\
\hline Level of education & -.801 & .424 & 3.561 & 1 & .059 & .449 \\
\hline Types of Containers for carrying waste & 2.220 & .526 & 17.827 & 1 & .000 & 8.883 \\
\hline Availability of Waste collection service & -21.441 & 4.938E3 & .000 & 1 & .997 & .000 \\
\hline Responsibility of waste collection & 2.257 & 4.101E4 & .000 & 1 & 1.000 & 9.554 \\
\hline Willingness to pay for wastes collection & -15.318 & 4.142E4 & .000 & 1 & 1.000 & .000 \\
\hline Waste by-laws existence & .357 & .569 & .393 & 1 & .531 & 1.428 \\
\hline Enforcement of waste by-laws & .662 & .570 & 1.351 & 1 & .245 & 1.939 \\
\hline Availability of Bylaws & -.545 & .400 & 1.856 & 1 & .173 & .580 \\
\hline High benefits of waste re use & -.957 & .723 & 1.754 & 1 & .185 & .384 \\
\hline Availability of adequate disposal Space & -4.403 & 1.077 & 14.737 & 1 & .000 & .012 \\
\hline Sensitization on waste management & 2.589 & 1.310 & 3.903 & 1 & .048 & 13.311 \\
\hline $\begin{array}{l}\text { Evidence of legal steps taken on } \\
\text { indiscriminate dumping }\end{array}$ & -5.156 & 2.078 & 7.600 & 1 & .008 & .006 \\
\hline Constant & 37.846 & 7.633E3 & .000 & 1 & .996 & $2.731 \mathrm{E} 16$ \\
\hline
\end{tabular}


Table 5: Statistical test for suitability of the model

\begin{tabular}{lll}
\hline Test Statistics & Value & Significance \\
\hline Number of Observations & 200 & \\
-2 Log-Likelihood & 142.6 & \\
Cox and Snell R ${ }^{2}$ & 0.38 & \\
Nagelkerke R ${ }^{2}$ & 0.5 & \\
Chi-square & 98.2 & 0.0000 \\
Percent Correct Prediction & 88.0 & \\
\hline
\end{tabular}

Level of significance at 0.001

Efficiency and Reliability of the Solid Waste Management System

The statement of efficiency and reliability was used to bring out the household perceived performance of the solid waste management system in Lira municipality. The study used the terms efficiency and reliability as indicators to measure the performance.

\section{The Efficiency of the Solid Waste Management} Operation

Here the study focused on the collection frequency, collection entity, time at which collection operation takes place, and transport mechanism adequacy (Table 6). Solid waste collection frequency in Lira municipality is on both a daily and weekly basis. Waste collection pattern is determined by the generated quantity and its regularity. Lira Municipal Council (LMC) bears the greatest responsibility in solid waste management while any other organization working in waste management section would solicit consent from it. solid waste operation in the municipality takes place only during day time; especially in the early morning, afternoon, and late evening hours. The result indicates the inadequate number of waste collection vehicles to manage services in the whole municipality.

Table 6: Efficiency of solid waste management system ( $\mathrm{N}=200)$

\begin{tabular}{lll}
\hline Variable & Description & $\mathbf{f ( \% )}$ \\
\hline Collection frequency & Daily & $140(70)$ \\
& Weekly & $60(30)$ \\
\hline Collection entity & L.M.C & $171(89)$ \\
& Private & $29(15)$ \\
\hline Time of collection & Day only & $171(86)$ \\
& Day and night & $29(15)$ \\
\hline Transport mechanisms adequacy & Yes & $9(5)$ \\
& No & $178(89)$ \\
& I do not know & $13(7)$ \\
\hline
\end{tabular}

\section{Reliability of Solid Waste Management Operation}

Here the study focused on the mechanical condition of garbage trucks, solid waste collection coverage, waste by-laws existence, and By-laws enforcing entity. The result indicates that the garbage trucks in use are in very poor mechanical condition (Table 7). Not all areas within the municipality are covered by solid waste collection/management operations of the municipal council. Plate 1 demonstrates how unreliable the garbage trucks are in Lira Municipality. The study also noted that waste management by-laws do exist but they are not being implemented. It also revealed that Local council leaders are supposed to implement solid waste management by-laws together with municipal health officers and municipal environmental scouts but both the latter have neglected their duties. 
Plate 1: Roadside waste disposal along Rwot Aler road in Lira Municipality

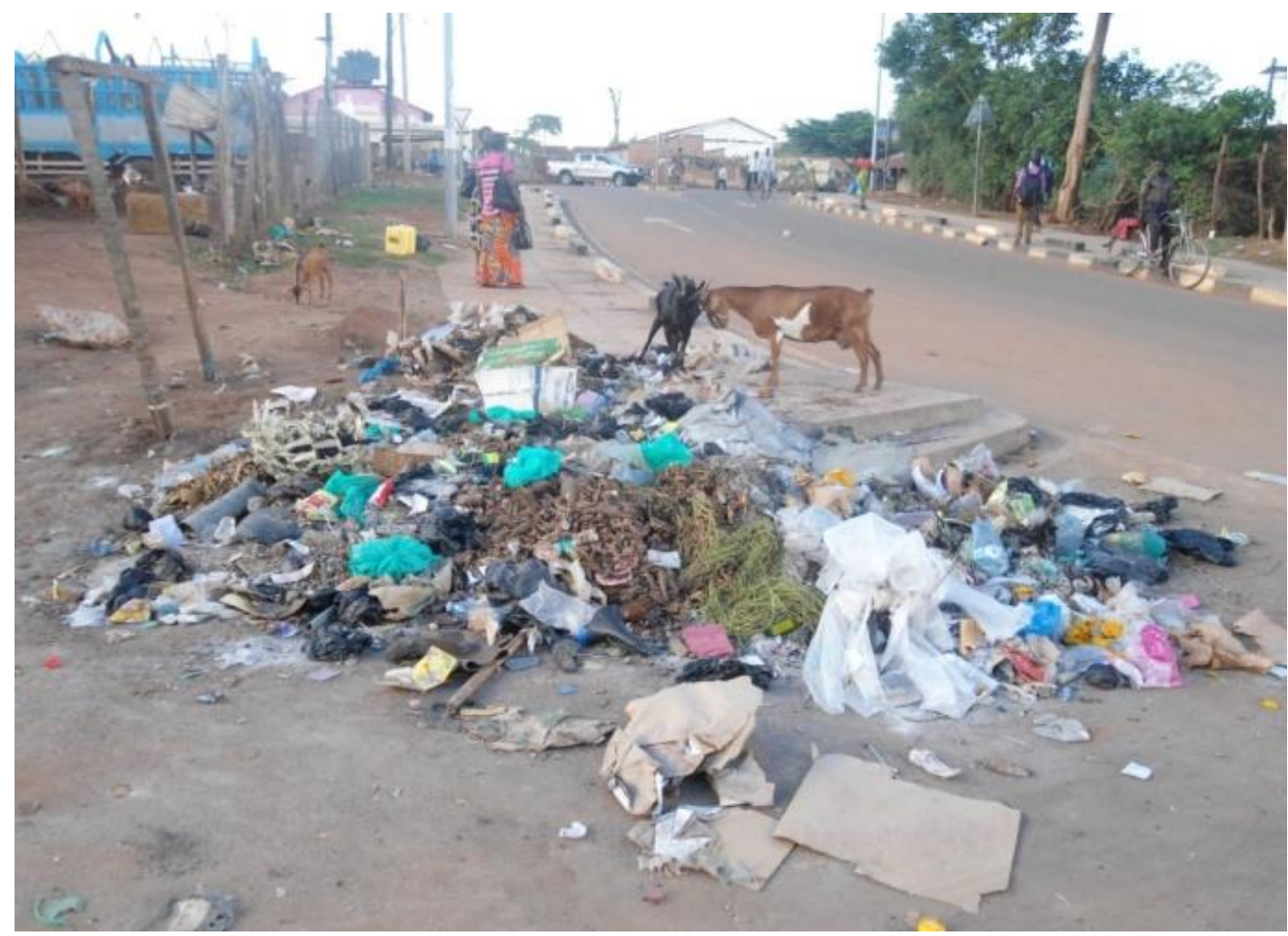

Table 7: Reliability of Lira municipal solid waste management operations

\begin{tabular}{lll}
\hline Variable & Description & $\mathbf{f ( \% )}$ \\
\hline Mechanical condition of vehicles (garbage trucks) & Poor & $168(84)$ \\
& Good & $11(6)$ \\
& I do not know & $21(12)$ \\
\hline Coverage of collection operations & Not all Areas & $166(83)$ \\
& All areas covered & $23(11)$ \\
& I do not know & $10(5)$ \\
\hline Existence of waste by-laws & No & $75(38)$ \\
& Yes & $72(36)$ \\
& I do not know & $53(27)$ \\
\hline Entity that enforces the by-laws & Local council/Village Health Teams & $112(56)$ \\
& Environmental scouts & $21(11)$ \\
& Health hygiene officers & $31(20)$ \\
& All the above & $28(14)$ \\
\hline
\end{tabular}

Constraints and Opportunities of Solid Waste Management in Lira Municipality

The study focused on constraints encountered from the collection, transportation, and disposal. Inadequate space was identified at all stages, such as at collection points and for temporal dumping to await final disposal collection (Table 8). The solid waste crew do not wear protective gears such as nose masks, mouth masks, over rolls, gumboots, and rubber gloves during collection, sorting, transportation, and during final disposal. Their health safety is therefore not so much considered thus exposing them to respiratory tract infections and other skin infections. Delayed schedules for collection are identified at all levels from household 
storage points for areas with community collection containers or waiting points and delay in removal from temporal dump sites for final disposal due to the inadequate number of garbage trucks which are as well in poor mechanical condition. poor attitude by both workers and community was identified at all stages starting from households up to disposal. Here people do not sort the solid wastes generated, workers do not also sort waste collected. Some people in the Community still indiscriminately dump wastes in trenches, at roadsides, and behind isolated unfinished buildings.
Inadequate storage facility was reported one of the constraints as most households lacked solid waste storage facilities at collection stage. They use old sacks, old buckets which would break up during waste transportation to temporal collection points and usually package all waste in the same container. No any other container is provided for waste sorting/ separation. legal enforcement on indiscriminate solid waste dumping was also found highly lacking at disposal stage. Waste dumping in trenches on streets and in un-finished buildings would be curbed down if solid waste by-laws were being strictly enforced by all stakeholders at all levels.

Table 8: Constraints in municipal waste management in Lira municipality $(\mathrm{N}=\mathbf{2 0 0})$

\begin{tabular}{lc}
\hline & $\mathbf{f}(\boldsymbol{\%})$ \\
\hline Collection operation & $61(30)$ \\
\hline Inadequate collection points & $50(25)$ \\
Lack of safety precautions (nose and mouth masks, gloves, gumboots etc.) & $45(23)$ \\
Delayed schedules & $21(10)$ \\
Workers attitudes & $13(7)$ \\
Lack of trained staff & $10(5)$ \\
Storage facilities (waste bins) & \\
\hline Sorting & $60(30)$ \\
\hline No sensitization of people on waste handling & $50(25)$ \\
Poor -not sorting waste & $45(23)$ \\
No safety gears & $45(23)$ \\
Transporting facilities & \\
Few garbage trucks and in sorry states & $168(84)$ \\
Accessibility in some areas-bad roads & $32(16)$ \\
\hline Disposal & \\
\hline Poor attitude by community-indiscriminate dumping & $86(43)$ \\
Inadequate space due to land tenure system & $72(36)$ \\
No sensitization on dangers of indiscriminate dumping & $27(14)$ \\
Lack of legal enforcement by government on illegal dumping & $15(8)$ \\
\hline
\end{tabular}

\section{Opportunities}

Focus on opportunities was basically on positive economic, social, health, and environmental-related matters that the current waste management system offers for exploitation or investment (Figure 4). Results indicated that recyclables like discarded pieces of iron, plastic water bottles, broken plastic items and metallic scraps such as broken metallic chairs and metallic bars, old discarded car parts constitute source of earning as they are collected by many idle people, street dwellers and later sold to dealers who take them for re-modification to factories; hence provide earnings. Municipal solid waste management is an employment entity. Many people are employed as solid waste collectors, street sweepers, garbage truck drivers by Lira Municipal council waste management section where they earn monthly wage payment. Waste management activities provide for a disease and vector free environment when solid waste is collected and disposed of properly as items that would act as their breeding grounds will have been removed. Thus, protects health and life. Lastly, it provides a revenue 
stream to Lira Municipal council government; especially from sale of compost manure from Aler solid waste composting plant.

Figure 3: Opportunities prevalent in the municipal solid waste management system of Lira Municipality

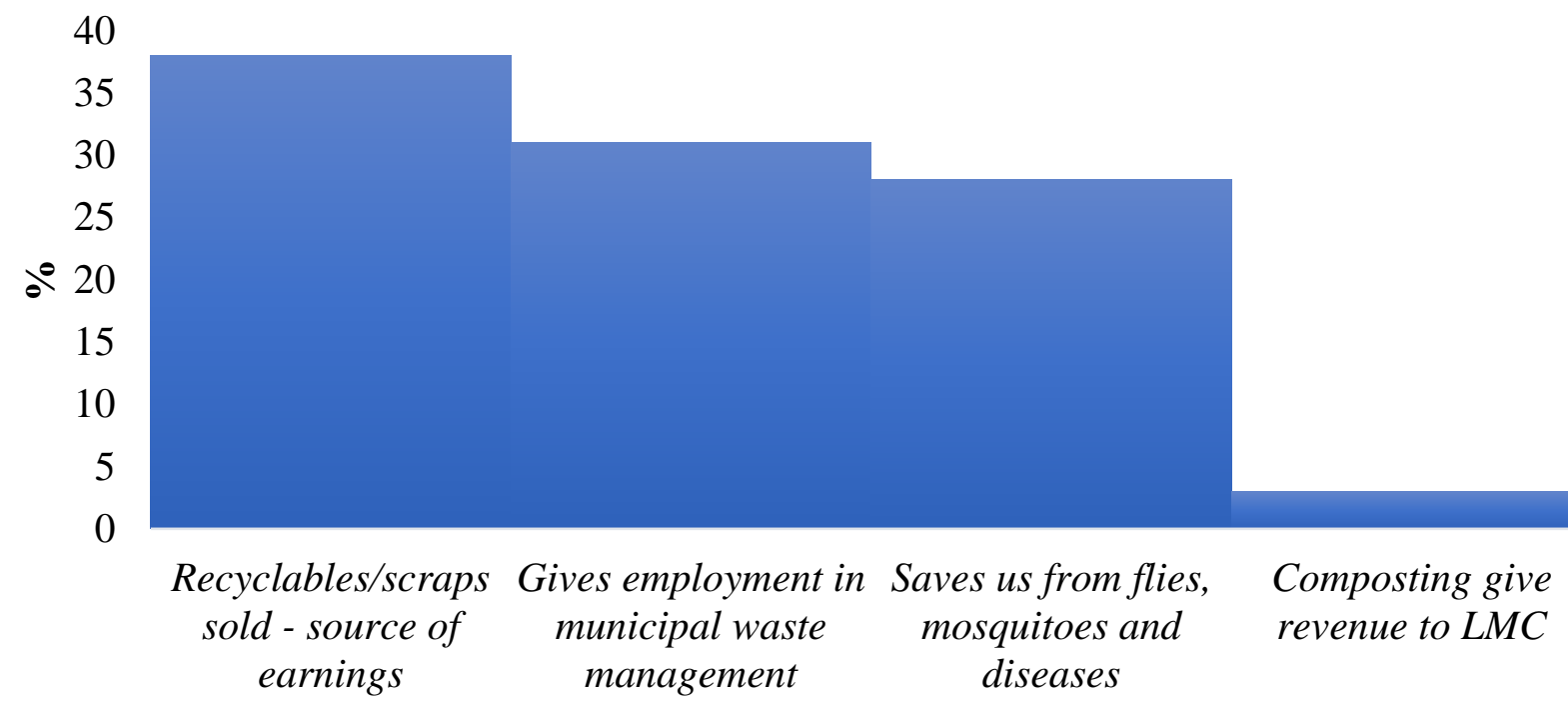

\section{Opportunities}

\section{DISCUSSION}

Organic biodegradable solid wastes are the commonest in the waste stream of Lira Municipality, constituting 63.2\%; especially vegetation matter, food waste, sawdust and paper. This finding is in agreement with report from study by Franca et al. [20] which said much of the solid municipal waste produced in African cities has high percentage of organic waste which was estimated at $57 \%$, while $13 \%$ was plastic, $9 \%$ paper, $4 \%$ glass, $4 \%$ metals and $13 \%$ comprise other materials and are usually with high moisture content. The study finding portrayed some uniqueness in that; on any type of waste generated vegetable matter and plastic would be most generated; and also, street debris which would be neglected from the waste classification is gaining prominence in the waste streams. The pattern of organic biodegradable could arise as a result of location factor whereby being located within the tropical belt supporting the growth of many herbages which constitute a larger percentage of the people's diet and plastic could be from the use of packed bottle water in fear of pipe water which many people believe is contaminated by leachates from garbage soup into the springs and pipe perforations.

At household level, solid waste packaging/ storage traditional back yard mode is highly practised though at a slightly closer range with a polythene bag and community collection bin. This finding conforms with the study by Tassie-Wegedie [21] in Bahir City-Ethiopia which found that households without communal collection container or personal collection containers use two options, that is; simply burning, burying or dumping of solid waste in compounds, or throwing waste indiscriminately at road sides, open fields. This study clearly reveals that solid waste collection container is a function of household sanity in any municipal setting. The study also revealed that Lira Municipal council waste management unit holds full responsibility in managing the collection of all solid waste in the municipal areas. This finding conforms to the Uganda Local Government Act [22] which stipulates that the Engineering Departments within the local government of each district or Municipality is held responsible for the provision of transport and collection facilities for solid waste 
while National Environmental Management Authority (NEMA) and Public Health Department bear responsibility for environmental protection. The study also pointed out that open dumping is the commonest method of solid waste dumping being practiced followed by landfill. This finding is consistent with earlier study findings by Tassie [23] which reported that open dumping is the most widespread method of solid waste disposal in most urban centres in developing countries and it typically involves the uncontrolled disposal of waste without measures to control leachate, dust, and odours. These results reveal that people yet do not clearly distinguish between the landfill and open dump making them not feel bad. People should, therefore, be made aware of the clear distinctions between a landfill and open dump and be educated on the merits of using sanitary landfill instead of the open dump.

Most households use hired labour to take their household wastes to temporal collection points. This report is in agreement with earlier study by Tassie-Wegedie [21] in Ethiopia which says households in the low and medium density zones receive door to door solid waste collection due to their willingness to pay some fees to the collectors for financing waste management. The study found household age a cardinal factor influencing solid waste collection and dumping. Here 'who' takes the waste to the temporal dump matters; whether young or adult persons given that knowledge on improper waste risk with regards to practices such as throwing waste daily, keeping waste near or outside the door and inadequate safety behaviours of not maintaining sanity nearby are prominent with young people aged between $15-25$ years. This finding is consistent with an earlier study by Mamady [24] in West Africa where people of ages between 15-25 years were found often would dispose of waste in open land spaces. Therefore, with the coefficient of 1.5 and significance level of 0.000 which below 0.001 posing marginal effect of 3.8, any increase in age would raise effective waste collection and dumping by $38.38 \%$ due to their safe environmental awareness and concern as the greatest age range in the study at this time comprise people below 30 years of age. Solid waste packaging and carrying containers was found also a great determinant. With a coefficient of 2.2 and significance level of 0.000 which is below 0.001 and with the marginal effect of 8.8 any improvement in waste carrying containers to the central dumping ground would give $88.4 \%$ improvement in efficient and effective collection and proper dumping. Containers should be durable, easy to handle, economical and resistant to corrosion. The containers should be seated in the proper location of distance, convenient, compatible and safe as was also noted by Mamady [24] in their earlier studies in Guinea.

Presence of adequate collection/dumping space (Space) was revealed greatly influenced collection and dumping of solid waste. With a coefficient value of -4.133 and significance level of 0.000 which is below 0.001 shows that effective collection and dumping degenerates by $0.12 \%$; which means an increase in indiscriminate dumping in event of few temporal dumpsites to contain the growing population and expanding municipal area. This finding agrees with Awumbila [25] which found that increasing per capita generation of solid waste and lack of land conveniently situated for waste disposal, all point to a rapid further aggravation of the already acute problems of solid waste management. Thus, the need for more space for collection and dumping.

Legal enforcement against illegal and indiscriminate dumping was found very necessary to restrain community from the bad act. With a coefficient of 0.008 which is quite below 0.001 and marginal effect of 0.006 means that relaxation to prosecute offenders of indiscriminate collection and dumping will increase indiscriminate dumping by 6\%. Indiscriminate disposal acts should therefore be treated as real crime and the Penalties should be high enough to motivate for. This finding agrees with earlier submission by Yukalang et al. [26] which noted that lack of enforcement of policies and laws is a major institutional management constraint of solid waste in the developing world. Although the finding of this research shows that other factors such as Education, attitude, sensitization, willingness to pay, and budgetary constraints do not affect solid waste collection and dumping in Lira municipality they may still be prominent factors in other municipalities.

Solid waste collection in the lira municipality is done on both a daily and weekly basis. This finding disagrees with study reports by Mukama et al. [27] 
in some East African cities and by Arogundade [28] in the Horn of Africa which cited irregular collection services and low collection coverage. The unique issue with Lira municipal solid waste collection strategy is that the pattern is determined by the generation quantity and its regularity. Also, there is a high level of coordination and collaboration between the Municipal government leaders, Lira media houses, health and environment department and the municipal dwellers who would report missing links to be sorted immediately. The study also reveals that solid waste collection operation in Lira municipality is a day time activity since the gravity of the work would not warrant it up to night time. Inadequacy of transport mechanisms was further noted. This finding agrees with the Aryampa [29] most urban centres in Uganda would require 50 garbage trucks to achieve the required level of operation.

The study reveals of poor mechanical conditions of the transport mechanisms in use are undependable. This finding agrees with earlier study findings by Ma and Hipel [30] in Ghana and Fredrick and Oonyu [31] in Kampala city which said the garbage trucks were in poor condition and constantly breakdowns on the roads rendering collection processes unreliable and ineffective. Waste vehicle mechanical condition is thus a factor in waste management reliability. Waste management service does not cover all areas of the municipality. This finding is consistent with earlier study by Ahsan [32] in India which found the unplanned city settlements make it difficult to reach other areas. There is thus need to have all areas under municipal coverage planned. There was not also any clear statement and implementation of enabling by-laws in waste management in Lira municipality. This finding is in agreement with earlier reports by Akpoborie [33] in Benin Metropolitan City and Okot-Okumu and Nyenje [34] in the cities of East Africa which pointed on legal constraints affecting waste management including inadequate enabling laws, regulations, standards, policies and inadequate enforcement of the existing laws, political interference.

Inadequate space was at all stages, such as at collection points and for temporal dumping. The finding is consistent with previous study by Yukalang et al. [26] in India who found that inadequate disposal ground is a factor that contributes to infrastructural challenges in waste management in developing nations and another earlier study by Miezah et al [35] in Ghana who noted that there was a lack of proper disposal sites in the country which resulted to Unprotected and uncontrolled dumps, which pose a danger to the public health, environmental health, waste renewable resources, and jeopardize residential development in these areas. For the case of Lira municipality, it has led to a unique invention in that the municipal waste crew would decide to identify some unbusy streets and use the sides as temporal dumps in the evenings to await collection very early in the morning daily. This calls for land purchase by the Municipal government as a redress to the problem.

Inadequate number of waste trucks was identified by the study. This finding matches the earlier study report by Sallwey et al. [36] who pointed that inefficiency and non-reliability in the solid waste collection and dumping service stem from inadequate collection vehicle and in their poor mechanical conditions. This submission is not any different from that of Lira municipality whereby the two trucks are not only old but in poor mechanical state and break down anywhere at any time. There is thus need for new trucks in sound mechanical state for good work delivery. Lack of protective gears for solid waste collection crews such as nose masks, mouth masks, over rolls, gumboots, and rubber gloves to use at work was an important constraint noted by the study. This finding is consistent with the report by Okot-Okumu [37] in East Africa which noted that most solid waste workers do not use protective gears during their works which render them vulnerable to aesthetic problems. A solid waste crew of lira complained about this problem as mandatory for their health. The study also requests Lira Municipal council local government to address for the good health of her workforce as working without protection exposes them to respiratory tract infections and other skin diseases as their skin barely get in touch with the rotten waste and other poisonous/ toxic matters in the waste streams.

Poor attitude by the community towards waste management such as not sorting waste at household levels was also revealed by the study. Here the 
households just dump waste in waste containers without sorting. This problem goes hand in hand with inadequate sensitization on solid waste handling techniques. Household community usually does not segregate their waste according to degradability yet it is a necessity. This finding agrees with prior study by Mrayyan and Hamdi, [38] which held that the low level of awareness regarding the health and environmental impacts of improper management of solid waste makes it difficult to implement recycling and disposal programs in many developing countries. This knowledge gap affects the success of activities like composting and recycling. The community should, therefore, be sensitized on waste handling processes.

Inadequate solid waste storage facilities at household levels were identified as a cardinal constraint. This finding is in agreement with an earlier study by Hazra and Goel [39] in India who found that poor conditions of containers and inadequate maintenance and replacement of wornout collection containers contributed to behaviours such as littering and illegal dumping by citizens who felt they could not properly dispose of trash because trash bins and waste services were not properly maintained. For Lira municipality, it was found that households with waste collection containers were descent while those without had waste littered all around. The study, therefore, forwards for the imposition of waste collection container to be made a must in all households in Lira municipality.

Lack of sensitization and enforcement of solid waste by-laws on indiscriminate disposals by responsible leaders was pointed by the study as a very prominent constraint. This finding is consistent with [40] who pointed out that this lack of enforcement of policies and laws is a major institutional issue that greatly contributes to the mismanagement of solid waste in the developing world. An example was Kenya which was cited that although has sufficient legislation covering waste management, local authorities cannot implement them which again Henry et al. [41] pointed that failure by their leaders to mount laws against littering by the community as social pressure to prevent littering, absence of realistic penalties or consistent enforcement, and lack of knowledge of the environmental effects of littering has had no impact but aggravated solid waste littering. Local leaders in Lira municipality as well are adamant to sensitization and punishing people against illegal and indiscriminate dumping which to the study is the genesis of these vices. Waste by-laws and penalties should be implemented.

The study reveals that solid wastes; especially recyclables and scraps provide a source of earnings when they are collected and sold to the buyers by some people buying them in the municipality. This finding is consistent with previous study by Shyam et al. [42] in India who found out that the recovery of reusable materials as plastics, paper and metals is performed by people working in the informal sector driven by poverty and this activity acts as the source of income to many poor communities. In Lira municipality metallic and plastic/synthetic product waste of all categories are collected for sale by jobless people, street children and even the municipal waste crews sort these recyclables from the waste streams they collect and again sell to the scrap dealers to get money. This confirms it to be a source of earning to some people.

The study revealed that municipal solid waste activities provide for a disease and vector free environment when solid wastes are collected and disposed properly. This finding agrees with research documentation by Al-Khatib et al. [40] which observes that waste management protects health and life as it reduces exposure to hazardous matter while contributing sanity and removing the unwanted byproducts and pollutants providing for a disease-free and fresh environment. People of Lira municipality believes that solid waste management activities like collection and disposal saves the environment from flies, mosquitoes and other vectors that cause diseases to the community. Hence confirms that it provides a disease and vector free environment.

Lastly, the research findings established that solid waste management is a lucrative investment to the government. This finding agrees with Seadon [43] which says that the revenues generated by the waste management through recycling and composting would top by $\$ 60$ million by 2018 . In Lira compost manure is made from sorted biodegradable solid waste from Aler solid waste composting plant. This is usually sold to needy progressive farmers and the revenue goes to Lira municipal local government 
account. Thus, confirms that it a lucrative investment to the government.

\section{CONCLUSION}

Organic biodegradable solid wastes are the commonest in the waste stream at $63.2 \%$; and street debris which would be neglected from the waste classification is gaining prominence in the waste streams. Traditional back yard solid waste packaging mode, polythene bag and community collection bin are highly practiced. Lira Municipal council local government holds full responsibility in managing the collection and disposal of all solid waste in the municipality. Open dumping is the commonest method of solid waste dumping being practiced followed by landfill in Lira municipality. Most households in Lira municipality use hired labour to take their household wastes to temporal collection points.

Solid waste collection in the lira municipality is done daily during the day time in the heart of the municipality and weekly at the peripherals. The collection strategy pattern is determined by the generation quantity and its regularity and is highly collaborative.

The major constraints to waste management are inadequate space for temporal dumping to await final disposal collection leading to temporal roadside packing of waste, inadequate number of waste trucks, lack of protective gears, and poor attitude by the community towards waste management such as not sorting waste at household levels. Others include inadequate solid waste storage facilities at household levels, and Lack enforcement of solid waste by-laws on indiscriminate disposals by the municipal leaders which augment the bad practices of indiscriminate disposal.

Solid wastes; especially recyclables and scraps provide a source of earnings to the most urban poor community. Municipal solid waste activities provide for a disease and vector free environment. Solid waste provides a revenue stream to the government (It constitutes a lucrative investment to the government)

The determinants of waste collection and dumping include Age, waste carrying containers, presence of adequate collection/dumping space (Space) also greatly influences the collection and dumping of solid waste. More space for collection and dumping would help to fight against environmental littering in the municipality. Legal enforcement/ step against illegal and indiscriminate dumping are very necessary to restrain the community from the bad actors as it motivates compliance.

\section{REFERENCES}

[1] Tai J, Zhang W, Che Y, Feng D., 2011. Municipal solid waste source-separated collection in China: A comparative analysis. Waste management. Aug 1; 31(8):1673-82.

[2] Chidiebere, O.A., Abubakar, M. and Shabako, J.G., 2018. Municipal Solid Waste Management in African Cities: A Case Study of Lagos State, Nigeria. Malaysian Journal of Civil Engineering, 30(1).

[3] Ozcan, H.K., Guvenc, S.Y., Guvenc, L. and Demir, G., 2016. Municipal solid waste characterization according to different income levels: A case study. Sustainability, 8(10), p.1044.

[4] Hoornweg, D., and Bhada-Tata, P. 2012. What a waste: a global review of solid waste management.

[5] Lohri, C. R., Camenzind, E. J., and Zurbrügg, C. 2014. Financial sustainability in municipal solid waste management-Costs and revenues in Bahir Dar, Ethiopia. Waste management, 34(2), 542-552.

[6] Binswanger-Mkhize, H., and McCalla, A. F. 2010. The changing context and prospects for agricultural and rural development in Africa. Handbook of agricultural economics, 4, 35713712.

[7] May, J., and Rogerson, C. M. 1995. Poverty and sustainable cities in South Africa: The role of urban cultivation. Habitat international, 19(2), 165-181.

[8] Omekwe 2017. Socio-Economic Variables and Solid Waste Generation and Management in Part Harcourt Metropolis, River State, Nigeria; 
SCIREA Journal of Economics: Volume 2, Issue 2, April 2017

[9] Kinobe, J.R., Niwagaba, C.B., Gebresenbet, G., Komakech, A.J. and Vinnerås, B., 2015. Mapping out the solid waste generation and collection models: The case of Kampala City. Journal of the Air and Waste Management Association, 65(2), pp.197-205.

[10] Oberlin, A.S. and Szántó, G.L., 2011. Community level composting in a developing country: case study of KIWODET, Tanzania. Waste Management \& Research, 29(10), pp.1071-1077.

[11] Chinasho, A., 2015. Review on community based municipal solid waste management and its implication for climate change mitigation. American journal of scientific and industrial research, 6(3), pp.41-46.

[12] Fenta, B.A., 2017. Waste management in the case of Bahir Dar City near Lake Tana shore in Northwestern Ethiopia: A review. African Journal of Environmental Science and Technology, 11(8), pp.393-412.

[13] Kaza, S., Yao, L., Bhada-Tata, P. and Van Woerden, F., 2018. What a waste 2.0: a global snapshot of solid waste management to 2050. The World Bank.

[14] Uganda Bureau of Statistics (UBOS), 2016, The National Population and Housing Census 2014 - Main Report, Kampala, Uganda.

[15] Abate, B. and Goshu, G., 2017. Waste management in lake tana basin-Case of rapidly urbanizing Bahir Dar City. In Social and ecological system dynamics (pp. 581-593). Springer, Cham.

[16] Agea, J.G., Obua, J., Kaboggoza, J.R. and Waiswa, D., 2007. Diversity of indigenous fruit trees in the traditional cotton-millet farming system: the case of Adwari subcounty, Lira district, Uganda. African Journal of Ecology, 45, pp.39-43.

[17] Ongoma, V., Chen, H. and Omony, G.W., 2018. Variability of extreme weather events over the equatorial East Africa, a case study of rainfall in Kenya and Uganda. Theoretical and applied climatology, 131(1-2), pp.295-308.

[18] James, P., 2014. Urban sustainability in theory and practice: circles of sustainability. Routledge.

[19] Kish, L. and Hess, I., 1959. On variances of ratios and their differences in multi-stage samples. Journal of the American Statistical Association, 54(286), pp.416-446.

[20] Franca, L.S., Rocha, M.S. and Ribeiro, G.M., 2018. Carbon Footprint of Municipal Solid Waste Considering Selective Collection of Recyclable Waste. In Environmental Carbon Footprints (pp. 79-112). ButterworthHeinemann.

[21] Tassie Wegedie, K., 2018. Determinants of peri-urban households' livelihood strategy choices: An empirical study of Bahir Dar city, Ethiopia. Cogent Social Sciences, 4(1), p. 1562508 .

[22] Government of Uganda (GoU). 1997. The Local Governments Act

[23] Tassie, K., Endalew, B. and Mulugeta, A., 2019. Composition, Generation and Management Method of Municipal Solid Waste in Addis Ababa City, Central Ethiopia: A Review. Asian Journal of Environment \& Ecology, pp.1-19.

[24] Mamady, K., 2016. Factors influencing attitude, safety behaviour, and knowledge regarding household waste management in Guinea: a cross-sectional study. Journal of environmental and public health, 2016.

[25] Awumbila, M., 2017. Drivers of migration and urbanization in Africa: Key trends and issues. International Migration, 7, p.8.

[26] Yukalang, N., Clarke, B. and Ross, K., 2017. Barriers to effective municipal solid waste management in a rapidly urbanizing area in Thailand. International journal of environmental research and public health, 14(9), p.1013. 
[27] Mukama, T., Ndejjo, R., Musoke, D., Musinguzi, G., Halage, A.A., Carpenter, D.O. and Ssempebwa, J.C., 2016. Practices, concerns, and willingness to participate in solid waste management in two urban slums in central Uganda. Journal of environmental and public health, 2016. Article ID 6830163, 7 pages. http://dx.doi.org/10.1155/2016/6830163

[28] Arogundade, T.T., Yawson, E.O., Gbadamosi, I.T., Abayomi, A.T., Tokunbo, O.S., Lambe, E., Bamisi, O.D. and Alabi, A.S., 2018. Behavioural cellular and neurochemical alterations in rat prefrontal cortex and hippocampus exposed to tigernut (Cyperus esculentus) treatment. Journal of Environmental Toxicology and Public Health, 3, pp.38-46

[29] Aryampa, S., Maheshwari, B., Sabiiti, E., Bateganya, N.L. and Bukenya, B., 2019. Status of Waste Management in the East African Cities: Understanding the Drivers of Waste Generation, Collection and Disposal and Their Impacts on Kampala City's Sustainability. Sustainability, 11(19), p.5523.

[30] Ma, J. and Hipel, K.W., 2016. Exploring social dimensions of municipal solid waste management around the globe-A systematic literature review. Waste Management, 56, pp.312.

[31] Fredrick, M. and Oonyu, J.C., 2019. Challenges faced by government and the private sector in the collection and disposal of solid waste in Kampala City, Uganda. African Journal of Environmental and Waste Management ISSN, 6(6), pp.001-012.

[32] Ahsan, N., 1999. Solid waste management plan for Indian megacities. Indian Journal of Environmental Protection, 19, pp.90-95.

[33] Akpoborie, I.A., 2011. Regulatory mechanisms for underground waste disposal in Nigeria: review and implications for environmental management. Journal of Applied Sciences and Environmental Management, 15(4), pp.539-546.
[34] Okot-Okumu, J. and Nyenje, R., 2011. Municipal solid waste management under decentralisation in Uganda. Habitat International, 35(4), pp.537-543.

[35] Miezah, K., Obiri-Danso, K., Kádár, Z., FeiBaffoe, B. and Mensah, M.Y., 2015. Municipal solid waste characterization and quantification as a measure towards effective waste management in Ghana. Waste Management, 46, pp.15-27.

[36] Sallwey, J., Hettiarachchi, H. and Hülsmann, S., 2017. Challenges and opportunities in municipal solid waste management in Mozambique: a review in the light of nexus thinking. AIMS Environ. Sci, 4, pp.621-639.

[37] Okot-Okumu, J., 2012. Solid waste management in African cities-East Africa. Waste Management-An Integrated Vision. DOI: $10.5772 / 50241$

[38] Mrayyan, B. and Hamdi, M.R., 2006. Management approaches to integrated solid waste in industrialized zones in Jordan: A case of Zarqa City. Waste Management, 26(2), pp.195-205.

[39] Hazra, T. and Goel, S., 2009. Solid waste management in Kolkata, India: Practices and challenges. Waste management, 29(1), pp.470478.

[40] Al-Khatib, I.A., Monou, M., Zahra, A.S.F.A., Shaheen, H.Q. and Kassinos, D., 2010. Solid waste characterization, quantification and management practices in developing countries. A case study: Nablus district-Palestine. Journal of environmental management, 91(5), pp.11311138 .

[41] Henry, R.K., Yongsheng, Z. and Jun, D., 2006. Municipal solid waste management challenges in developing countries-Kenyan case study. Waste management, 26(1), pp.92-100.

[42] Shyam, G.K., Manvi, S.S. and Bharti, P., 2017, February. Smart waste management using Internet-of-Things (IoT). In 2017 2nd international conference on computing and 
International Journal of Advanced Research, Volume 3, Issue 1, 2021

Article DOI: https://doi.org/10.37284/ijar.3.1.431

communications technologies (ICCCT) (pp. 199-203). IEEE.

[43] Seadon, J.K., 2006. Integrated waste management-Looking beyond the solid waste horizon. Waste management, 26(12), pp.13271336.

149 | This work is licensed under a Creative Commons Attribution 4.0 International License 